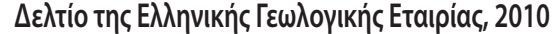

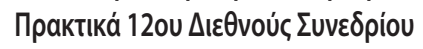

Пátрa, Máıǫ 2010
Bulletin of the Geological Society of Greece, 2010

Proceedings of the 12th International Congress

Patras, May, 2010

\title{
PATTERNS OF DUCTILE DEFORMATION IN ATTICO-CYCLADIC MASSIF
}

\author{
Spanos D., Koukouvelas I., Kokkalas S. and Xypolias P. \\ University of Patras, Department of Geology, Laboratory of Structural Geology, 26500 Patras, \\ Greece,spanos@upatras.gr
}

\begin{abstract}
The area of Lavrion constitutes the westernmost part of the Attico-Cycladic massif where the allochthonous Cycladic Greenschist-Blueschist unit overthrusts the para-authochthonous Basal unit. The tectonic contact of these units forms a crustal scale thrust zone which is the continuation of the Evia thrust. Our research was focused on quartz-rich schists of the overlying allochthonous unit. Combination of microstructural, finite strain data and quartz and calcite c-axis fabrics analysis was used to characterize the kinematics of rock flow within the thrust zone. The latter was formed under conditions of progressive exhumation and decompression of the high-pressure schists of the AtticoCycladic massif. A dominant top-to-the-ENE sense of shearing along the thrust zone is inferred by several shear sense criteria. The analysis of several specimens collected from various structural depths manifest that the deformation close to the thrust zone occurred under approximately plane strain conditions and was characterized by an Rxz strain ratio which fluctuates between 3 and 6.5 .
\end{abstract}

Key words: finite strain, quartz c-axis fabrics, calcite c-axis fabrics, exhumation, Attico-Cycladic massif, Lavrion.

\section{Introduction}

Over the last decades, there is a strong debate in the Attico-Cycladic massif (ACM) about the direction of nappes movement that led to the upsurge of the HP/LT rocks from deeper floors of the crust as well as about the prevalent exhumation mechanism. Although numerous studies were done in Evia and the islands of Cyclades, the region of Attica didn't receive similar attention.

In the southern part of Attica (Lavrion area) we implemented a combined analysis consisting of calcite and quartz c-axis fabrics and the evaluation of finite strain data in order to examine the kinematics of rock flow in a crustal scale ductile shear zone. Crystallographic preferred orientation (CPO) of minerals constitutes a widely used criterion for evaluating shear sense in ductile thrust zones (Law, 1990). Identification of kinematic indicators can confirm the results of petrofabric analysis or imply individual deformation events. On the other hand, strain analysis can decipher the conditions that predominate within the deformed rocks of the area. Furthermore, we present first results of calcite c-axis analysis from three representative samples collected from strongly deformed marbles from the thrust zone.

\section{Geological setting}

The area of Attica comprises the westernmost extension of the Attico-Cycladic Massif (ACM). The 


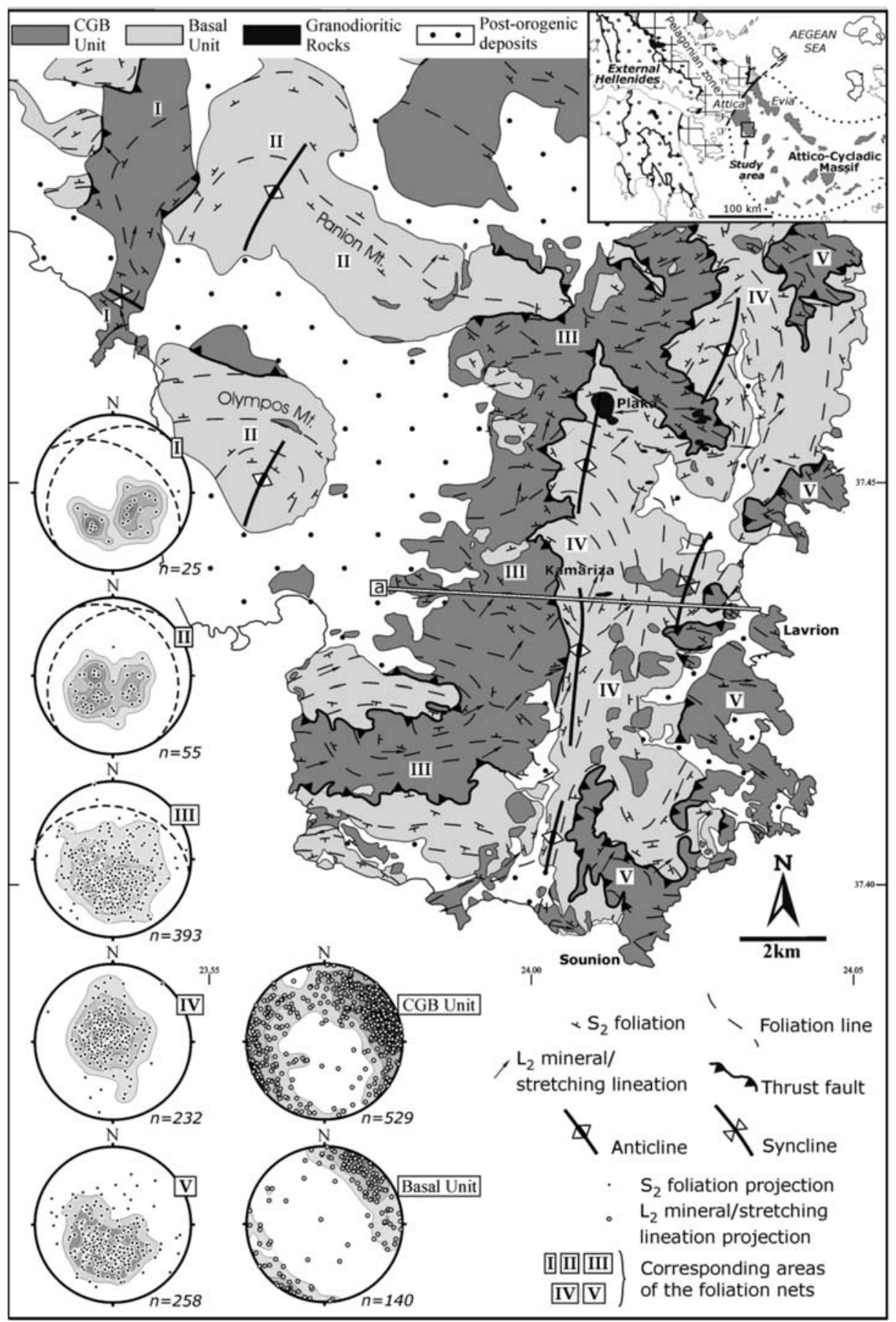

Fig. 1: Simplified geological map showing also foliation trajectories and mineral lineation trends. Lower hemisphere equal-area projections I-V reflect the foliation measurements of the corresponding areas in the map; also quoted the stretching lineation projections of the two main tectonic units; (inset): Generalized tectonic map shows the location of the Lavrion area and the Attico-Cycladic Massif within the Hellenides. 
ACM has an internal position within the Alpine orogenic belt of the Hellenides (Fig. 1 inset) and exposes a complex pile of high-pressure (HP) nappes/units, which are tectonically overlain by the Pelagonian zone, a belt of imbricated pre-Alpine crystalline rocks and Mesozoic marbles also belonging to the Internal Hellenides (Mountrakis, 1986; Doutsos et al., 1993; Anders et al., 2007).

In Lavrion area the ACM is divided into two major structural units: the para-authochthonous Basal unit at the bottom, which is considered to be the equivalent of Almyropotamos unit in Evia, and the overlying allochthonous Cycladic Greenschist-Blueschist (CGB) unit (Marinos \& Petrascheck, 1956; Katsikatsos et al., 1986). These two units are separated by a major ductile thrust (Kessel, 1990; Avigad et al., 1997; Xypolias et al., 2003). Hereinafter, this zone will be referred as 'Basal thrust'; it is equivalent to the Evia thrust.

The Basal unit is characterised of thick series of Mesozoic marbles and schists with minor lenses of mafic and ultramafic rocks, overlain by a metapelitic sequence, which is interpreted as metaflysch. In Lavrion area the relatively autochthonous Basal unit can be subdivided into: a) the lowermost "Lower Marble", b) the "Kamariza-Kesariani Schists" and c) the uppermost "Upper Marble". This succession of marbles and schists is at least $850 \mathrm{~m}$ thick and is considered to be of Upper TriassicJurassic age according to preserved fossils found in the broad area of Attica (Marinos \& Petrascheck, 1956; Photiades \& Carras, 2001 and references therein). During the Miocene, an I-type granodiorite (known as "Plaka granodiorite") intruded the Basal unit causing the metamorphism of the adjacent schists (Marinos \& Petrascheck, 1956; Skarpelis et al, 2008; Stouraiti, 2009).In Evia, glaucophane relics and Si-rich phengites in the metapelitic sequence were observed impling that the Basal unit underwent HP-metamorphism $\left(\sim 350^{\circ} \mathrm{C} / 8-10 \mathrm{kbar}\right.$; c. 30-35 km depth; Shaked et al., 2000). The possible age of this HP-event is early Miocene (Ring \& Reischmann, 2002) or preMiocene with early Miocene greenschist-facies overprinting (Bröcker et al., 2004) or late EoceneOligocene (e.g. Avigad et al., 1997).

The CGB unit overlies the Basal unit and, apart from the area of Attica, is emerged also in Evia and the islands of Cyclades. In the area of Lavrion, represented by a nappe formed of a thin (up to 250m) metasedimentary succession of schists with quartzites intercalations and calcite-rich marbles, as well as meta-ophiolite mafic bodies. Moreover, this nappe is homologous to the structurally lower Styra nappe of CGB in southern Evia (Katzir et al., 2000; Shaked et al., 2000). The CGB unit includes an epidote - blueschist facies metamorphism $\left(\mathrm{M}_{1}, \mathrm{~T}_{\max }=450^{\circ} \mathrm{C} ; \mathrm{P}_{\min }=11 \mathrm{kbar} ;\right.$ depth $>40$ $\mathrm{km}$ ) of Eocene age (c. 50-40 Ma), followed by a greenschist to pumpellyite - actinolite facies overprint $\left(\mathrm{M}_{2}, \mathrm{~T}_{\max }=350^{\circ} \mathrm{C} ; \mathrm{P}=4-7 \mathrm{kbar} ; \mathrm{c} .15-25 \mathrm{~km}\right.$ depth) at the Oligocene - Miocene boundary (c. 25 Ma) (Altherr et al., 1979; Bröcker, 1990; Baltatzis, 1996; Shaked et al., 2000; Tomascheck et al., 2003; Bröcker, et al. 2004). Alternatively, Baziotis et al. (2009) calculated lower P-T conditions for $\mathrm{M}_{1}\left(\mathrm{P} \sim 9 \mathrm{kbar}, \mathrm{T} \sim 350^{\circ} \mathrm{C}\right)$ and $\mathrm{M}_{2}\left(\mathrm{P} \sim 6 \mathrm{kbar}, \mathrm{T} \sim 280^{\circ} \mathrm{C}\right)$ metamorphic events. Research regarding the CGB unit that outcrops in southern Evia, imply that peak metamorphic conditions of the $\mathrm{M}_{1}$ event slightly increase towards the upper structural levels while the greenschist facies overprint $\left(\mathrm{M}_{2}\right)$ was characterized by a decrease in $\mathrm{M}_{2}$ temperature towards the base of the unit (Shaked et al., 2000; Katzir et al., 2000). The degree of retrogression in the ACM considerably increases downward and pervasively overprinted greenschist facies rocks predominate at the lower structural levels of the CBG unit resulting to the partial or complete effacement of the high pressure $\mathrm{M}_{1}$ assemblages (Bröcker et al., 2004 and references therein).

\section{Main structures and fabrics}

The deformed rocks of the CGB nappe preserve proto-mylonitic up to ultra-mylonitic textures. The 
second are located at the deeper structural levels of the nappe. The mylonitic foliation $\left(\mathrm{S}_{\mathrm{m}}\right)$ is defined by planar aggregates of the greenschist facies related minerals such as white mica and albite, and fine grained recrystallized quartz. The $\mathrm{S}_{\mathrm{m}}$ bears a well-developed ENE-WSW trending stretching lineation $\mathrm{L}_{\mathrm{m}}$. In low strain domains, an earlier residual $\mathrm{S}_{1}$ foliation is identified and has been isoclinally folded with contemporaneous development of axial planar foliation $\left(\mathrm{S}_{2}\right)$ and an accompanying stretching lineation $\mathrm{L}_{2}$. The axial planar foliation $\left(\mathrm{S}_{2}\right)$ represents the dominant fabric in the area (Fig. 1). In the CGB unit, $S_{2}$ generally plunges gently to north and swings to east or west depending the orientation of the contact with the underlying Basal unit. In the Basal unit $\mathrm{S}_{2}$ trends mostly N-S, dipping west and turning upon east forming N-S to NNE-SSW anticlines. The most representative ones are situated in Panion Mt., Olympos Mt. and southern of Kamariza settlement (Fig. 1). Both, $\mathrm{S}_{2}$ and the accompanying lineation $\mathrm{L}_{2}$ are subparallel to $\mathrm{S}_{\mathrm{m}}$ and $\mathrm{L}_{\mathrm{m}}$ respectively.

Beneath the thrust plane is located a c. $50 \mathrm{~m}$ thick zone of strongly foliated to (ultra-) mylonitized marbles of the Basal unit. A shallow ENE-WSW trending stretching lineation $\left(\mathrm{L}_{\mathrm{m}}\right)$ is defined by micaceous streaks on mylonitic foliation planes of impure marbles. Thin ultramylonites locally display a roughly N-S trending lineation (Fig. 1), which is interpreted to reflect 'rolling' lineation development as described by Passchier (1997). In the deeper structural levels of the Basal unit in Attica, compositional layering $\left(\mathrm{S}_{1}\right)$ is strongly deformed by tight to isoclinal, map-scale, ductile folds and a series of east-directed ductile shear zones. The axial-planar foliation $\left(\mathrm{S}_{2}\right)$ of these folds as well as the shear zones are sub-parallel or at low angle to the thrust.

\section{Microstructural and petrofabric analysis}

Microstructural and petrofabric data from 3 oriented calcite-rich and 15 quartz-rich samples that located in the thrust zone are summarized in Figure 2a. Locations of all samples have also been projected on a representative geological cross-section (Fig. 2b). The estimated sampling distances of each sample measured perpendicular to the thrust planes are given in Table 1, where the positive and negative values of depth correspond to samples above (CGB unit) and below (Basal unit) the thrust plane respectively.

All microstructural and crystal fabric data were taken from thin-sections oriented parallel to the stretching lineation (X) and perpendicular to the foliation (XY). Petrofabric analysis of quartz caxis and calcite c-axis preferred orientation was carried on $\mathrm{XZ}$ thin-sections using a Leitz universal stage mounted on an optical microscope.

\subsection{Microstructures}

In all quartz-rich samples, quartz exceeds $75 \%$ of total sample composition and shows evidence of extensive dynamic recrystallization accommodated by either subgrain rotation or low-temperature grain-boundary migration (i.e. transitional between regime 2 and regime 3 of Hirth \& Tullis 1992). The volume fraction of quartz recrystallization within samples ranges between $60 \%$ and $90 \%$. Highly elongate ribbon grains lying in the plane of foliation $\left(\mathrm{S}_{\mathrm{m}}\right)$ are locally preserved. Dynamically recrystallized quartz grains are also elongate with their long axes oriented obliquely to the $\mathrm{S}_{\mathrm{m}}$ or parallel to it in domains with relatively high phyllosilicate content. Oblique grain-shape fabric $\left(\mathrm{S}_{\mathrm{q}}\right)$ was locally recognized in 7 of the 18 samples selected for detailed analysis (Fig. 3c). The maximum observed angle between $S_{m}$ and $S_{q}$ generally varies from $10^{\circ}-20^{\circ}$ (Fig. 2a).

Similar angular relationships have been described elsewhere in quartz-rich tectonites that have undergone non-coaxial deformation (e.g. Law et al. 1986) and the sense of obliquity can be used as a shear sense indicator. A consistent top-to-the ENE shear sense is indicated by all the 7 quartz-rich 
(a)
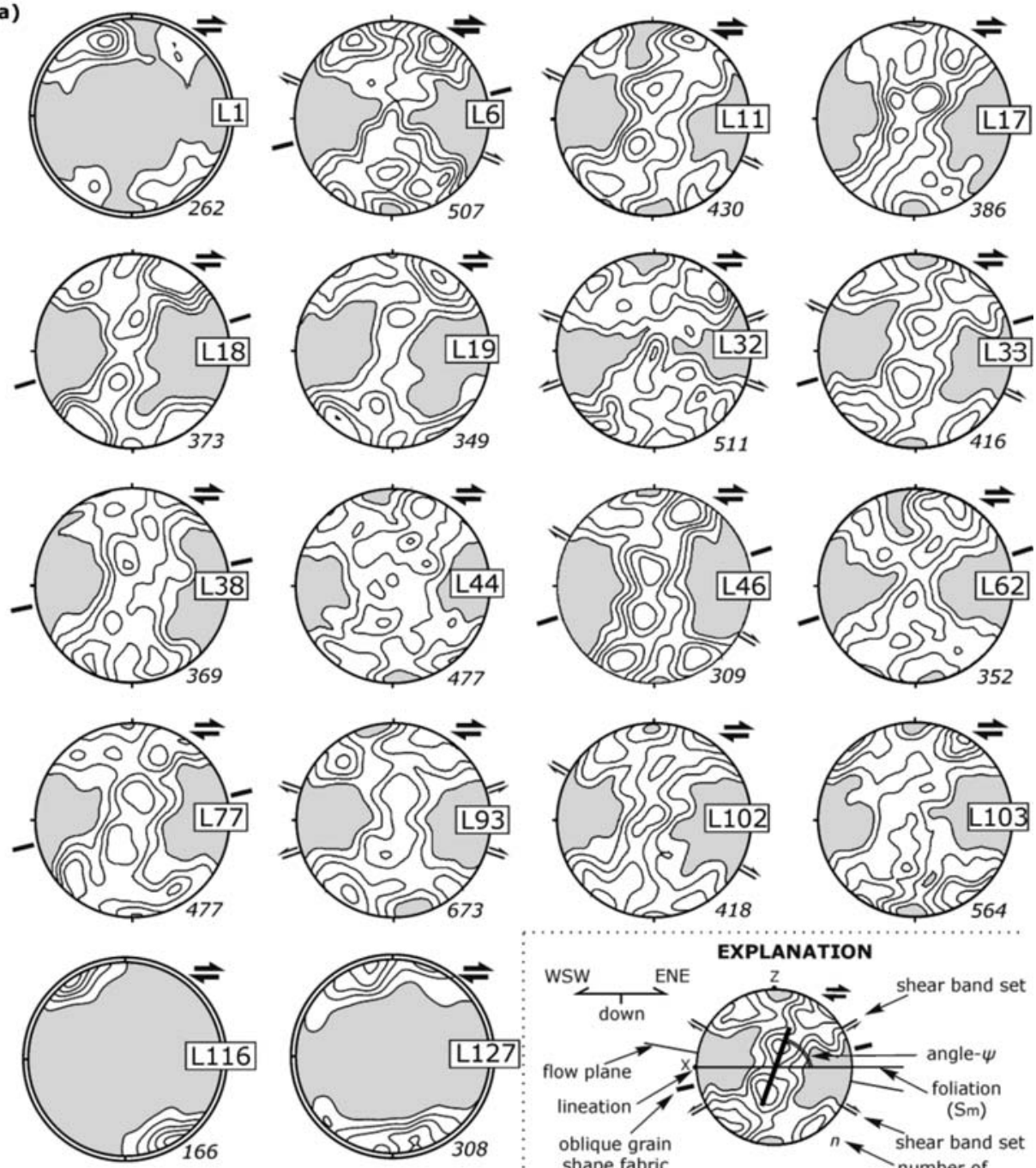

EXPLANATION
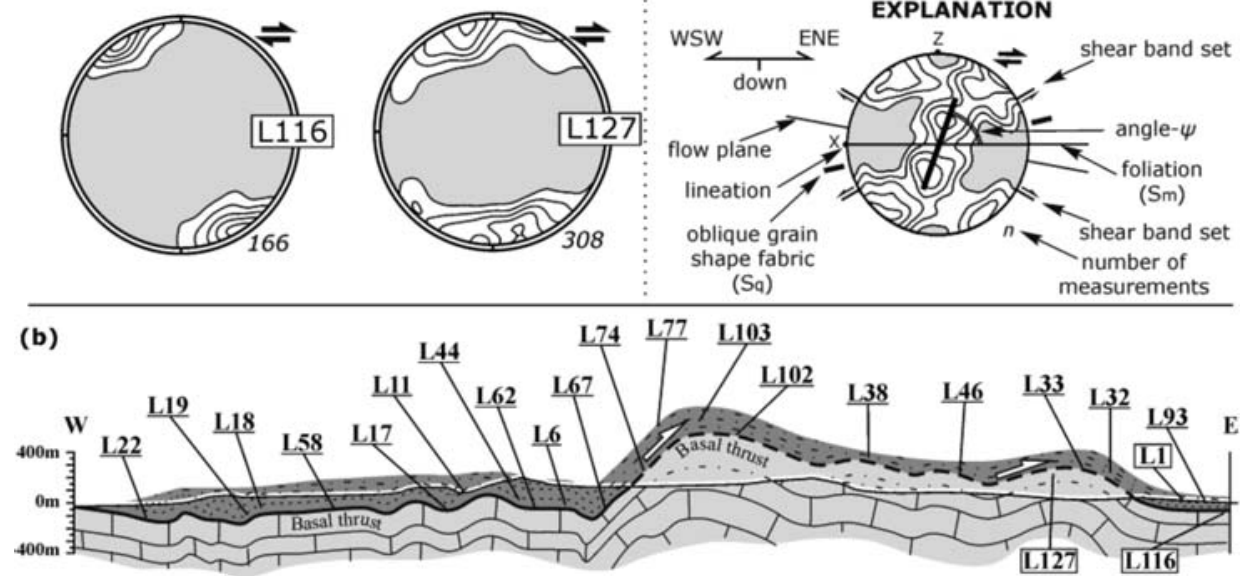

Fig. 2: (a) Contoured diagrams (Lower hemisphere equal-area projections) of optically measured quartz c-axes from 15 samples (after Xypolias et al. 2010) and calcite c-axis from three (L1, L116, L127; nets with double lined periphery) samples; all the XZ section planes are approximately viewed towards the NNW. Samples L116 and L127 were collected from the Basal unit while the rest from CGB unit. Orientations of oblique grain shape fabric $\left(\mathrm{S}_{\mathrm{q}}\right)$ and shear band sets have been marked for samples where these microstructures were observed. (b) $\mathrm{W}$-E cross-section showing the structural positions of the samples relative to basal thrust while the geographic co-ordinates of each sample locality are given in Table 1. 
tectonites displaying an obliquity between $\mathrm{S}_{\mathrm{m}}$ and $\mathrm{S}_{\mathrm{q}}$. The same shear sense is inferred from single sets of extensional shear bands (Platt \& Vissers 1980) observed in 4 samples containing domains of relatively high phyllosilicate content (Figs. 3a, 2a). The angle of obliquity between shear bands and $\mathrm{S}_{\mathrm{m}}$ ranges between $20^{\circ}$ and $35^{\circ}$. Weakly developed conjugate shear bands with top-to-the ENE and WSW senses of displacement are locally recorded in 2 samples (Fig. 2a). However, the top-to-the ENE set is dominant in the majority of the samples.

Some samples (e.g. L38, L67) contain rigid feldspar porphyroclasts that are oriented at various angles with respect to $S_{m}$. Elongate porphyroclasts oriented at moderate to high angles $\left(>30^{\circ}\right)$ to foliation display $\delta$ - or $\sigma$-tails and give consistent top-to-the-ENE sense of shear (Figs 3b). In turn, $\sigma$-type clasts oriented at low angles to $\mathrm{S}_{\mathrm{m}}$ indicate either top-to-the-ENE- or top-to-the-WSW-directed shearing with the direction to be dominant. These microstructural features possibly indicate a component of pure shear during ductile deformation (see also Simpson \& DePaor 1997; Klepeis et al. 1999).

\subsection{Quartz c-axis fabrics}

The majority of analyzed samples are characterized by well-developed quartz c-axis fabrics (Fig. 2a). The intensity of the crystallographic preferred orientation appears to be lower in one sample (L44). This sample contains a relatively high proportion (c. 20-25\%) of phyllosilicates and/or other mineral phases. All samples produce fabrics that generally exhibit similar characteristics (Fig. 2a). In terms of density distribution, the standard pattern is type-I cross-girdles (Lister 1977) with discrete and well-developed point maxima at moderate to high angles to the foliation trace.

Among the 15 quartz c-axis fabrics measured close to the thrust zone, 12 are distinctly asymmetrical (in terms of both topology and density distribution) with respect to foliation and lineation, indicating a top-to-the-ENE sense of shear (Fig. 2a). Less clearly defined fabric asymmetry consistent with ENE shear sense was recognized in three samples (L6, L17, L44; Fig. 2a). In all these fabrics, the inferred shear sense is supported by the obliquity (angle $\psi$ ) of the central girdle segment, which varies between 70 and $85^{\circ}$, as well as by microstructural shear sense indicators (where observed) described above (Fig. 2a). No unequivocal microstructural shear sense indicators were observed in these samples.

\subsection{Calcite c-axis fabrics}

The microscopic analysis of calcite has been restricted on determining the crystallographic preferred orientation (CPO) of the optical c-axis of calcite grains in three samples. Sample L1 comes from the CGB unit whilst samples L116 and L127 belong to marble-mylonites of the Basal unit. The objective of the calcite petrofabric analysis is the verification of shear sense via the orientation patterns of calcite grains and the correlation of the exported results with the ones of quartz c-axis. Calcite optical axis measurements were acquired using the procedure introduced by Turner \& Weiss (1963). The fabric asymmetry in all three samples documents top-to-the-ENE sense of shear which is concordant with quartz petrofabric analysis. According to the classification from Wenk et al. (1987), caxis distributions show triclinic symmetry that is characteristic of simple shear deformation. Pole figures of L1 and L127 are characterized by two major and two minor concentrations that imply higher temperatures than L116.

\section{Finite strain analysis}

Strain analysis was performed on 18 samples including elongate ribbon-like quartz grains. Two mutually perpendicular thin sections were cut from each specimen: one (XZ section) parallel to the lin- 


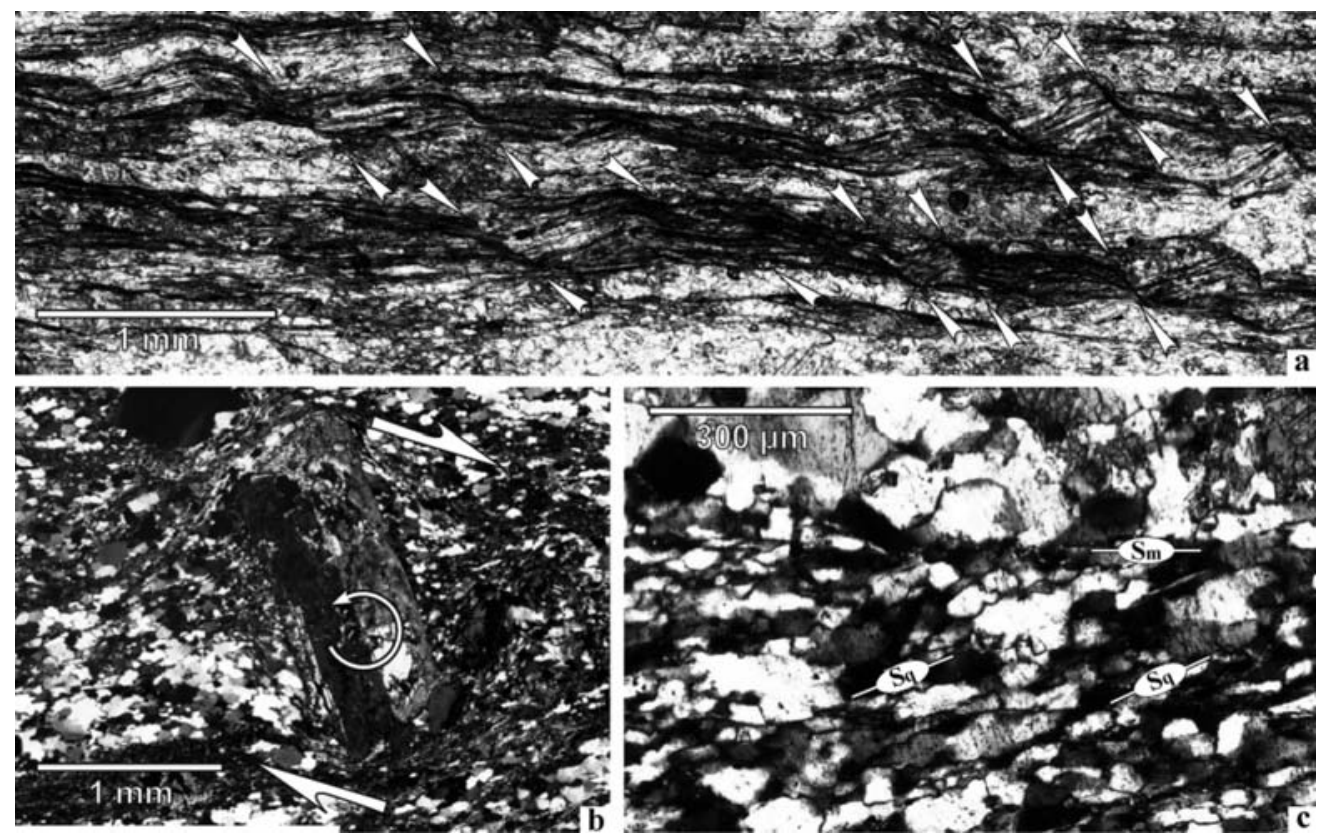

Fig. 3: Photomicrographs of microstructures in the CGB unit shot from thin sections cut perpendicular to foliation and parallel to stretching lineation and viewed towards the NNW; (a) Single set of shear bands in sample L67 indicating top-to-the-ENE sense of shear preferably developed in a phyllosilicate-rich domain inter-bedded in quartz Qtz-rich zones (plane polarized light); (b) Sample L38: backward rotated o-type plagioclase feldspar porphyroclast. The porphyroclast is embedded in ductily deforming matrix consisting of phyllosilicate and recrystallized quartz and mantled by wedge-shaped recrystallized tails extending from its broad sides indicating top-to-the ENE sense of shear (crossed polarized light); (c) Sample L17: elongate, dynamically recrystallized quartz grains displaying a preferred shape alignment $\left(\mathrm{S}_{\mathrm{q}}\right)$ oblique to the mylonitic foliation $\left(\mathrm{S}_{\mathrm{m}}\right)$. The obliquity reflects top-to-the ENE shear sense (crossed polarized light).

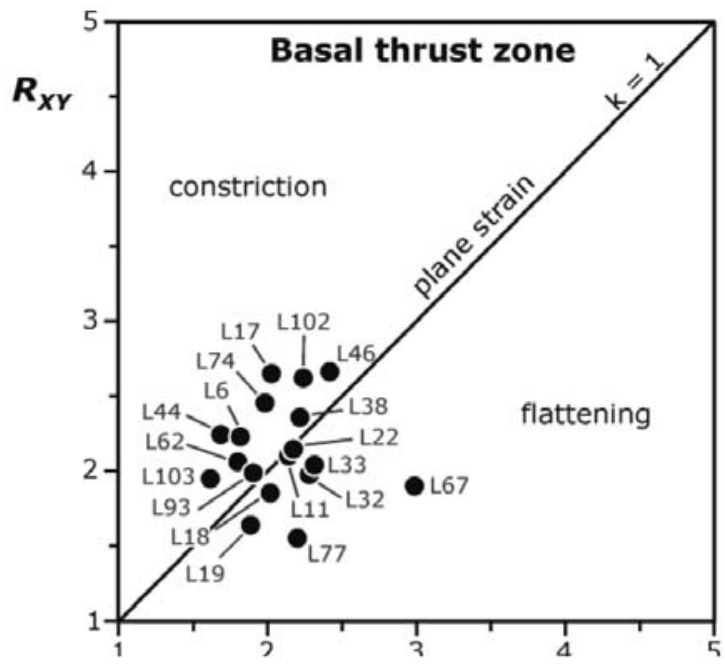

Fig. 4: Flinn diagram showing finite strain data collected from the Basal thrust zone (after Xypolias et al. 2010). 
eation and normal to the foliation and one (YZ section) perpendicular to both the lineation and foliation. In each section the traces of 100-150 grain outlines were input into the program SAPE (Mulchrone et al.2005), which automatically approximates complex grain shapes as ellipses and extracts Rf - $\phi$ data. The extracted data for each section were analysed using the theta-curve method of Lisle (1985). Calculations of best-fit $\mathrm{R}_{\mathrm{XZ}}$ and $\mathrm{R}_{\mathrm{YZ}}$ values were made utilizing the strain analysis program of Mulchrone \& Meere (2001). Maximum uncertainty in strain ratio has been estimated to be \pm 0.3 (see also Yonkee 2005; Xypolias et al. 2007). Assuming constant volume deformation, the 3D strain was determined by combining $2 \mathrm{D}$ data from the assumed $\mathrm{R}_{\mathrm{XZ}}$ and $\mathrm{R}_{\mathrm{YZ}}$ principal planes of the strain ellipsoid (Ramsay \& Huber, 1987). Results of the strain analysis are presented in Figure 4.

The $\mathrm{R}_{\mathrm{XZ}}$ strain ratio varies from 3.1 to 6.4 while the determined finite strain data attribute Flinn's parameter $(\mathrm{k})$ values that range between 0.45 (flattening strain) and 1.79 (constrictional strain). Although the values fall in both the apparent flattening and constrictional fields, they generally lie close to the plane strain line (average $\mathrm{k}=1.08$ ). This is in agreement with $3 \mathrm{D}$ strain data reported from the Evia thrust zone in central Evia area, where an average $\mathrm{k}=0.98$ has been obtained (Xypolias et al.2003).

\section{Discussion and conclusions}

Quartz-rich tectonites above the Basal thrust display a homogeneously developed, greenschist facies foliation $\left(\mathrm{S}_{\mathrm{m}}\right)$ and an ENE-trending mineral stretching lineation $\left(\mathrm{L}_{\mathrm{m}}\right)$. The deformation along the Basal thrust zone occurred under approximately plane strain conditions with a dominant top-to-the-ENE sense of shearing along the Basal thrust zone indicated by the asymmetry of quartz and calcite $\mathrm{c}$-axis fabrics with respect to foliation and lineation (Fig. 2). This inferred shear sense is independently supported by the observed sense of obliquity between foliation and shape preferred orientation of recrystallized quartz grains as well as by single sets of normal shear bands. An overall top-to-the-ENE movement sense has been documented in different structural levels of the ACM in central Evia (Xypolias et al., 2003) and neighbouring islands (e.g. Syros and Tinos, Trotet et al., 2001). In contrast, Ring et al. (2007) proposed WSW-directed emplacement of the CGB. Contradicting kinematic evidence for ENE- (e.g. Barton 1976; Doutsos et al. 1993) or WSW- (e.g. Schermer 1993) directed shearing has also been given for the tectonically equivalent nappe contact in the Mt. Olympos region (northern Greece.

The presence of conflicting kinematic indicators may be due to the different rate of emergence within different domains of the CGB unit although the en-
Table 1. Geographical coordinates for samples from the CGB unit.

\begin{tabular}{|c|c|c|c|}
\hline \multirow{2}{*}{ Sample } & \multicolumn{2}{|c|}{ Geographical coordinates } & \multirow{2}{*}{ D (m) } \\
\cline { 2 - 3 } & Latitude & Longitude & \\
\hline L77 & $37^{\circ} 46^{\prime} 41^{\prime \prime}$ & $24^{\circ} 01^{\prime} 36^{\prime \prime}$ & +180 \\
\hline L103 & $37^{\circ} 47^{\prime} 46^{\prime \prime}$ & $24^{\circ} 02^{\prime} 03^{\prime \prime}$ & +100 \\
\hline L1 & $37^{\circ} 43^{\prime} 21^{\prime \prime}$ & $24^{\circ} 04^{\prime} 24^{\prime \prime}$ & +75 \\
\hline L32 & $37^{\circ} 43^{\prime} 12^{\prime \prime}$ & $24^{\circ} 02^{\prime} 59^{\prime \prime}$ & +60 \\
\hline L11 & $37^{\circ} 43^{\prime} 40^{\prime \prime}$ & $23^{\circ} 59^{\prime} 13^{\prime \prime}$ & +60 \\
\hline L18 & $37^{\circ} 41^{\prime} 59^{\prime \prime}$ & $23^{\circ} 57^{\prime} 56^{\prime \prime}$ & +50 \\
\hline L19 & $37^{\circ} 41^{\prime} 57^{\prime \prime}$ & $23^{\circ} 57^{\prime} 32^{\prime \prime}$ & +50 \\
\hline L44 & $37^{\circ} 41^{\prime} 48^{\prime \prime}$ & $23^{\circ} 59^{\prime} 46^{\prime \prime}$ & +50 \\
\hline L38 & $37^{\circ} 39^{\prime} 58^{\prime \prime}$ & $23^{\circ} 59^{\prime} 27^{\prime \prime}$ & +40 \\
\hline L67 & $37^{\circ} 45^{\prime} 56^{\prime \prime}$ & $24^{\circ} 00^{\prime} 23^{\prime \prime}$ & +40 \\
\hline L93 & $37^{\circ} 44^{\prime} 39^{\prime \prime}$ & $24^{\circ} 03^{\prime} 46^{\prime \prime}$ & +35 \\
\hline L17 & $37^{\circ} 44^{\prime} 05^{\prime \prime}$ & $23^{\circ} 59^{\prime} 08^{\prime \prime}$ & +30 \\
\hline L6 & $37^{\circ} 43^{\prime} 13^{\prime \prime}$ & $24^{\circ} 00^{\prime} 03^{\prime \prime}$ & +30 \\
\hline L33 & $37^{\circ} 41^{\prime} 12^{\prime \prime}$ & $24^{\circ} 02^{\prime} 43^{\prime \prime}$ & +25 \\
\hline L62 & $37^{\circ} 45^{\prime} 31^{\prime \prime}$ & $23^{\circ} 59^{\prime} 55^{\prime \prime}$ & +15 \\
\hline L102 & $37^{\circ} 49^{\prime} 06^{\prime \prime}$ & $24^{\circ} 02^{\prime} 31^{\prime \prime}$ & +10 \\
\hline L22 & $37^{\circ} 41^{\prime} 14^{\prime \prime}$ & $23^{\circ} 56^{\prime} 17^{\prime \prime}$ & +10 \\
\hline L74 & $37^{\circ} 47^{\prime} 24^{\prime \prime}$ & $24^{\circ} 01^{\prime} 29^{\prime \prime}$ & +10 \\
\hline L46 & $37^{\circ} 40^{\prime} 25^{\prime \prime}$ & $24^{\circ} 01^{\prime} 34^{\prime \prime}$ & +3 \\
\hline L116 & $37^{\circ} 47^{\prime} 06^{\prime \prime}$ & $24^{\circ} 04^{\prime} 24^{\prime \prime}$ & -9 \\
\hline L127 & $37^{\circ} 44^{\prime} 37^{\prime \prime}$ & $24^{\circ} 03^{\prime} 05^{\prime \prime}$ & -38 \\
\hline
\end{tabular}

* For definition see Fig. 2a.

$D$, distance from the thrust plane; 
tire unit had ceaseless ENE movement. In that case, counter sense of shear is observed that testifies a relative movement between adjacent layers of the unit and not the bulk shear sense of CGB unit.

\section{References}

Altherr, R., Schliestedt, M., Okrusch, M., Seidel, E., Kreuzer, H., Harre, W., Lenz, H., Wendt, I., Wagner, G. A. 1979. Geochronology of high pressure rocks on Sifnos (Cyclades, Greece). Contributions to Mineralogy and Petrology, 70, 245-255.

Anders, B., Reischmann, T., Kostopoulos, D., 2007. Zircon geochronology of basement rocks from the Pelagonian Zone, Greece: constraints on the pre-Alpine evolution of the westernmost Internal Hellenides. International Journal of Earth Sciences, 96, 639-661.

Avigad, D., Garfunkel, Z., Jolivet, L., Azanon, J.M., 1997. Back arc extension and denudation of Mediterranean eclogites. Tectonics, 16, 924-941.

Baltatzis, E., 1996. Blueschist-to-greenschist transition and the P-T path of prasinites from the Lavrion area, Greece. Mineralogical Magazine, 60, 551-561.

Barton, C.M., 1976. The tectonic vector and emplacement age of an allochthonous basement slice in the Olympos area, N.E. Greece. Bulletin de la Société Géologique de France, 18, 253-258.

Baziotis, I., Proyer, A. and Mposkos, E., 2009. High-pressure/low-temperature metamorphism of basalts in Lavrion (Greece): implications for the preservation of peak metamorphic assemblages in blueschists and greenschists Eur. J.Mineral. 2009, 21, 133-148.

Bröcker, M., 1990. Blueschist-to-greenschist transition in metabasites from Tinos Island (Cyclades, Greece): Compositional control or fluid infiltration. Lithos, 25, 25-39.

Bröcker, M., Bieling, D., Hacker, B., Gans, P., 2004. High-Si phengite records the time of greenschist facies overprinting: Implications for models suggesting megadetachments in the Aegean Sea. Journal of Metamorphic Geology, 22, 427-442.

Doutsos, T., Piper, G., Boronkay, K., Koukouvelas, I., 1993. Kinematics of the Central Hellenides. Tectonics, 12, 936-953.

Hirth, G. and Tullis, J., 1992. Dislocation creep regimes in quartz aggregates. Journal of Structural Geology, 14, 145-159.

Katsikatsos, G., Migiros, G., Triantaphyllis, M., Mettos, A., 1986. Geological structure of Internal Hellenides. Institute of Geological and Mining Exploration, Athens. Geological and Geophysical Research, Special Issue, 191-212.

Katzir, Y., Avigad, D., Matthews, A., Gurfunkel, Z., Evans, B.W., 2000. Origin, HP/LT metamorphism and cooling of ophiolitic mélanges in southern Evia (NW Cyclades), Greece. Journal of Metamorphic Geology, 18, 699-718.

Kessel, G., 1990. Untersuchungen zur Deformation und Metamorphose in Attischen Krystallin, Griechenland. Berliner Geowissenschaftlicher Abhandlungen, A126, 1-150.

Klepeis, K. A., Daczko, N.R., Clarke, G.L., 1999. Kinematic vorticity and tectonic significance of superposed mylonites in a major lower crustal shear zone, northern Fiordland, New Zealand. Journal of Structural Geology, 21, 1385-1405.

Law, R.D., Casey, M., Knipe, R.J., 1986. Kinematic and tectonic significance of microstructures and crystallographic fabrics within quartz mylonites from the Assynt and Eriboll regions of the Moine thrust zone, NW Scotland. Transactions of the Royal Society of Edinburgh: Earth Sciences, 77, 99-126.

Law, R.D., Schmid S.M., Wheeler, J., 1990. Simple shear deformation and quartz crystallographic fabrics: a possible natural example from the Torridon area of NW Scotland. Journal of Structural Geology, 12, 29-45. 
Lisle, R.J., 1985. Geological Strain Analysis. A Manual for the $R_{f} / j$ method. Pergamon Press, New York.

Lister, G.S., 1977. Discussion: Crossed girdle c-axis fabrics in quartzites plastically deformed by plane strain and in progressive simple shear. Tectonophysics, 39, 51-54.

Marinos, G.P. and Petrascheck, W.E., 1956. Laurium. Geological and Geophysical Research 4/1, Institute for Geology and Subsurface Research, Athens, 1-247.

Mountrakis, D., 1986. The Pelagonian zone in Greece. A polyphase-deformed fragment of the Cimmerian continent and its role in the geotectonic evolution of the eastern Mediterranean. Journal of Geology, 94, 335-347.

Mulchrone, K.F. and Meere, P.A., 2001. Windows program for the analysis of tectonic strain using deformed elliptical markers. Computers and Geosciences, 27, 1251-1255.

Mulchrone, K.F., Meere, P.A., Roy Choudhury, K., 2005. SAPE: a program for semi-automatic parameter extraction for strain analysis. Journal of Structural Geology, 27, 2084-2098.

Passchier, C.W., 1997. The fabric attractor. Journal of Structural Geology, 19, 113-127.

Photiades, A. and Carras, N., 2001. Stratigraphy and geological structure of the Lavrion area (Attica, Greece). Bull. Geol. Soc. Greece. 34/1, 103-109.

Platt, J.P. and Vissers, R.L.M., 1980. Extensional structures in anisotropic rocks. Journal of Structural Geology, 2, 397-410.

Ramsay, J.G. and Huber, M.I., 1987. The Techniques of Modern Structural Geology, vol. 2. Academic Press, New York.

Ring, U. and Reischmann, T., 2002. The weak and superfast Cretan detachment, Greece: exhumation at subduction rates in extruding wedges. Journal of the Geological Society, London, 159, 225-228.

Ring, U., Glodny, J., Will, T., Thomson, S., 2007. An Oligocene extrusion wedge of blueschist-facies nappes on Evia, Aegean Sea, Greece: implications for the early exhumation of high-pressure rocks. Journal of the Geological Society, London, 164, 637-652.

Schermer, E.R., 1993. Geometry and kinematics of continental basement deformation during Alpine orogeny, Mt. Olympos region, Greece. Journal of Structural Geology, 15, 571-591.

Shaked, Y., Avigad, D., Garfunkel, Z., 2000. Alpine high-pressure metamorphism at the Almyropotamos window (southern Evia, Greece). Geological Magazine, 137, 367-380.

Simpson, C. and De Paor, D.G., 1997. Practical analysis of general shear zones using the porhyroclast hyperbolic distribution method: an example from the Scandinavian Caledonides. In: SENGUPTA, S. (ed.) Evolution of Geological Structures in Micro- to Macro-scales. London: Chapman \& Hall, 169-184.

Skarpelis, N., Tsikouras, B., Pe-Piper, G., 2008. The Miocene igneous rocks in the Basal Unit of Lavrion (SE Attica, Greece): petrology and geodynamic implications. Geological Magazine, 145, 1-15.

Stouraiti, C., Mitropoulos, P., Tarney, J., Barreiro, B., McGrath, A.M., Baltatzis, E., 2009. Geochemistry and petrogenesis of late Miocene granitoids, Cyclades, southern Aegean: nature of source components.

Tomaschek, F., Kennedy, A.K., Villa, I.M., Lagos, M., Ballhaus, C., 2003. Zircons from Syros, Cyclades, Greece-recrystallization and mobilization of zircon during high-pressure metamorphism. Journal of Petrology, 44, 1977-2002.

Trotet, F., Jolivet, L., Vidal, O., 2001. Tectono-metamorphic evolution of Syros and Sifnos islands (Cyclades, Greece). Tectonophysics, 338, 179-206.

Turner, F.J. and Weiss, L.E., 1963. Structural analyses of metamorphic tectonites.

Wenk, H.R., Takeshita, T., Bechler, E., Erskine, B.G., Matthies, S., 1987. Pure shear and simple shear calcite textures. Comparison of experimental, theoretical and natural data. Journal of Structural Geol- 
ogy, 9, 731-745.

Xypolias, P., Kokkalas, S., Skourlis, K., 2003. Upward extrusion and subsequent transpression as a possible mechanism for the exhumation of HP/LT rocks in Evia Island (Aegean Sea, Greece). Journal of Geodynamics, 35, 303-332.

Xypolias, P., Chatzaras, V., Koukouvelas, I. K., 2007. Strain gradients in zones of ductile thrusting: Insights from the External Hellenides. Journal of Structural Geology, 29, 1522-1537.

Xypolias, P., Spanos, D., Chatzaras, V., Kokkalas, S., Koukouvelas, I., 2010. Vorticity of flow in ductile thrust zones: examples from Attico-Cycladic Massif (Internal Hellinides, Greece). In: Law, R. D., Butler, R. W. H., Holdsworth, R., Krabendam, M. \& Strachan, R. (eds) Continental Tectonics and Mountain Building - The Legacy of Peach and Horne, Geological Society, London, Special Publications, 335, in press.

Yonkee, A., 2005. Strain patterns within part of the Willard thrust sheet, Idaho-Utah-Wyoming thrust belt. Journal of Structural Geology, 27, 1315-1343. 